Dept. of Poultry Diseases,

Fac. of Vet. Med., Assiut University

Head of Dept. Prof. Dr. El-Refai M. Refai

\title{
EPIDEMIOLOGICAL AND ULTRASTRUCTURAL STUDIES ON PIGEON POX IN UPPER EGYPT
}

(With 2 Tables and 11 Figures)

By

\section{SAIF-EDIN and S. S. EL-BALLAL*}

* Dept. of Pathology, Fac. of Vet. Med., Assiut Univ.

(Received at 3/3/1997)

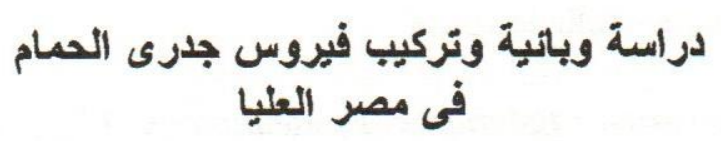

مصطفى سبف الدين ، صلاح البلام

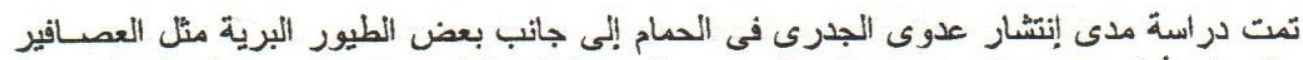

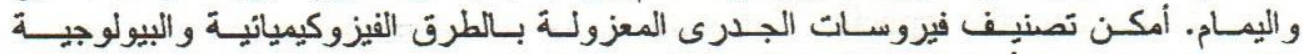

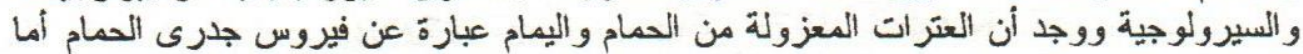

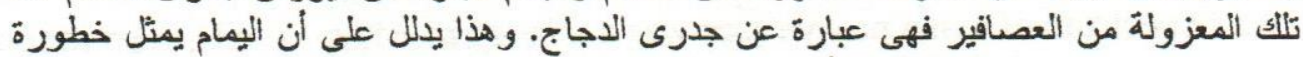

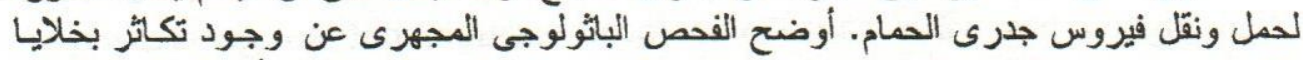

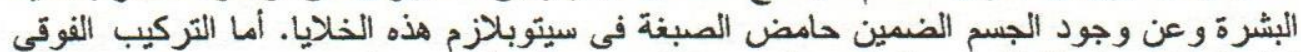

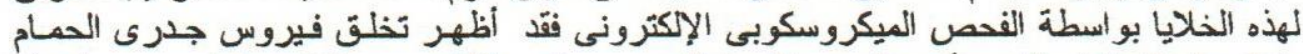

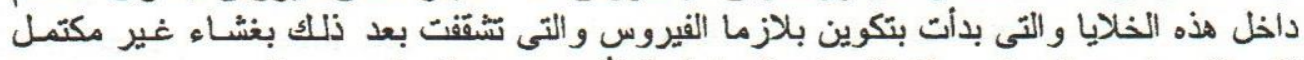

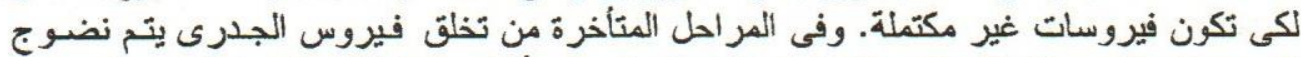

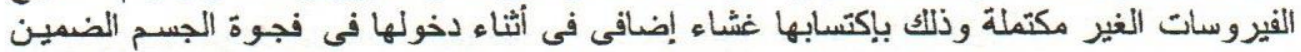

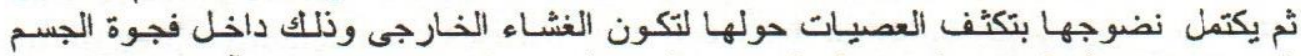

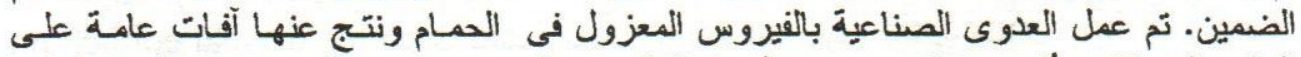

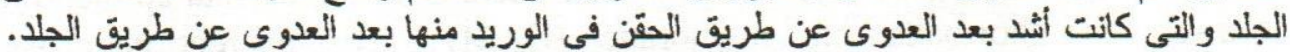

\section{SUMMARY}

The occurrence of pox virus infections in three species of exotic birds including pigeons, house sparrows (Passere domesticus) and doves was studied. Isolated pox viruses were identified physicochemically, biologically (host spectrum) and serologically. Isolates from pigeons and doves were characterized as pigeon pox virus, while the sparrows isolate was 
characterized as fowl pox virus. It seemed that doves are reservoir of infection to pigeons. Histopathological examination revealed that pigeon pox virus infection in pigeons resulted in epidermal hyperplasia with associated inflammatory resaction and formation of eosinophilic intracytoplasmic A-type inclusion bodies in the epithelial cells. Electron microscopic studies revealed that infected cells showed areas of viroplasm which was sequestrated to form viroplasmic particles. Maturation of these particles occurred by projection into the membrane of inclusion body vacuole where they obtain a membrane coat and arrangement of rodlets over the surface of the virion to form the external coat in the interior of the inclusion body. Experimental infection of pigeons with pigeon pox virus was manifested clinically by generalized cutaneous lesions which were more severe after intravenous (i.v.) inoculation than after the feather follicle route.

\section{Key words: Pigeon pox-Epidemiology-Upper Egypt.}

\section{INTRODUCTION}

Infection with pox viruses have been reported in domestic and in approximately 60 species of wild birds representing about 20 families (Kirmse, 1967; Karstad, 1971; Cunningham, 1972; Back et al., 1995). The host spectrum of avian pox viruses was explaned by Mayr (1963), who found that pigeon pox virus cause mild local reaction, but no generalized pox lesions in either chickens or turkeys, while generalized lesions were induced only in pigeons. He also found that turkey pox virus could affect ducks, while pigeon and fowl pox viruses failed to induce local or generalized lesions in ducks.

Morphologically, all avian pox viruses have the same ultrastructural details. The differentiation between these viruses has been attempted on the basis of host susceptibility, characteristic lesions on the dermal epithelium, growth on chorioallantoic membrane (CAM), cross-protection, crossneutralization, complement fixation, and agar-gel precipitation tests (Tripathy et al., 1973). Pandey and Mallick (1975) concluded that the production of pock lesions on the CAM and demonstration of intracytoplasmic inclusions are the criteria used for identification of avian pox viruses in addition to certain serological tests as agar gel precipitation (AGP) test and serum neutralization test.

Pigeon pox is an acute or subacute viral disease characterized by progressive wartlike eruptions forming scabs on the exposed surfaces of the 
body and thickened, yellowish, diphtheritic patches on mucous membranes (Tripathy, 1991;; Tudor, 1995).

The pigeon pox virus is classified under Group 2 of the family Poxviridae and in genus Avipoxvirus which includes fowl, turkey, pigeon, canary, quail, starling, junco, and sparrow pox as separate types of pox in birds (Matthews, 1982).

Doves can be infected naturally with pigeon pox (Kossack and Hanson, 1954) and experimentally via feather follicle route (El-Dahaby et al., 1971).

The A-type inclusion (ATI) is the characteristic product of poxvirus infection. It can be classified into two types, one including mature viruses $\left(\mathrm{V}^{+}\right.$character), and another containing no virus at all ( $\mathrm{V}^{-}$character). This character is genetically controlled traits which exist in virions independently of the capacity to produce infective virus (Shida et al., 1977; Sadasiv et al., 1985).

This study, deals with several outbreaks of avian pox among pigeon lofts in upper Egypt, identification of the etiological agent, predetection of possible sources of infection. Moreover the morphogenesis of pigeon poxvirus in the epithelial cells of pigeon squabs and its entrance into ATI was described ultrastructurally.

\section{MATERIALS and METHODS}

\section{Reference antisera:}

Reference avian pox antisera of fowl pox 1, pigeon pox, and turkey pox were kindly supplied by Prof. Dr. S. Mousa, Dept. of Poultry Diseases, Fac. of Vet. Med., Assiut University.

\section{Chicken embryo inoculation:}

Fertile eggs were obtained from the farm of Faculty of Agriculture, Assiut University, and incubated at $37 \mathrm{C}$ until used at 10 days for virus isolation and titration. Prepared inoculum in serial ten-fold dilutions were inoculated at $0.1 \mathrm{ml} / \mathrm{egg}$ via CAM by drop membrane method. Inoculated eggs were examined daily up to 7 days postinoculation for characteristic pock lesions on CAM. Titration end points of embryo infective dose fifty $\left(E_{50}\right)$ were calculated by the method of Reed and Muench (1938).

Specimens and virus isolation:

Samples collected from diseased and freshly dead pigeons, doves and sparrows from different localities in Upper Egypt showing suspected cutaneous or diphtheritic lesions of pox were subjected to virus isolation. 
Specimens were ground with sterile fine sand and suspended in saline. The suspension was centrifuged and antibiotics (penicillin and streptomycin) were added to the supernatant fluid and held at $4 \mathrm{C}$ for $1 / 2$ hour. The bacteria free suspensions were inoculated on the chorioallantoic membrane of 10-day-old developing chicken embryos by the drop membrane method. The inoculated eggs were incubated at $37 \mathrm{C}$ and candled daily for 6 days. The membranes were examined for presence of pock lesions and stored at $-20 \mathrm{C}$ until used.

\section{Stock virus suspension:}

Suspensions were inoculated onto CAM of embryonated chicken eggs and after 6 days of incubation the CAM's were harvested. A $10 \%$ suspension of CAM was prepared and titrated to contain about $3 \times 10^{8}$ $\mathrm{EID}_{50}$ per $\mathrm{ml}$. Aliquots of suspensions were stored at $-20 \mathrm{C}$ till used for experimental infections as well as tissue culture inoculation (Minbay and Kreir, 1973).

Experimental birds:

\section{1- One-day-old chicks:}

They were obtained from the farm of Faculty of Agriculture, Assiut University, and used for intravenous inoculation with isolated pox viruses.

\section{2- Pigeon squabs:}

3-4-week-old pigeon squabs were purchased from the local market and used for intravenous and feather follical inoculation with isolated pox viruses.

\section{3- Ducks:}

12-week-old ducks were purchased from the local market and used for $\mathrm{I} / \mathrm{V}$ inoculation with isolated pox viruses.

\section{4-Turkey poults:}

10-week-old turkey poults were supplied by Beni-suef turkey governmental farm and were used for $\mathrm{I} / \mathrm{V}$ inoculation with isolated pox viruses.

Agar gel precipitation (AGP) test:

The test was done as described by Cunningham (1966). Previously fowl pox and pigeon pox viruses infected CAM suspensions, were used as control antigens. Hyperimmune serum against fowl pox and pigeon pox viruses were prepared in rabbit (Gipsen, 1955) and used as positive control antisera.

\section{Neutralization test:}

Equal volumes of Ten-fold dilutions of isolated pox virus and specific antisera were incubated at $37 \mathrm{C}$ for two hours. The mixtures were then titrated on the CAMs of embryonated chicken eggs using $0.1 \mathrm{ml}$ of the 
mixtures per egg. The neutralization index was expressed as the log difference between the control virus titer and the titer of the virus after incubation with the specific antisera (Baxendale, 1971).

Haemagglutination (HA) test: (1971).

The isolated pox viruses were tested for HA activity after Annon

\section{Heat stability:}

Heat stability of the virus isolates were studied after Hass and Dardiri (1968). The isolates were exposed to $56 \mathrm{C}$ for 15,30 and $60 \mathrm{~min}$. treated and untreated isolates were sheked for infectivity by titration on CAM.

Ether and chloroform sensitivity:

The sensitivity of the virus isolates to $10 \%$ diethyl ether and $20 \%$ chloroform was done after Andrews and Horstmann (1949) and Feldman and Wang (1961). Treated and untreated control samples were checked for virus infectivity by titration on CAM of embryonated chicken eggs.

\section{Histopathological examination:}

Lesions of the skin and CAM were fixed in $10 \%$ neutral buffered formalin, dehydrated and embedded in paraffin wax. Tissue sections were stained with H.\&E for histopathological examination (Drury and Wallington, 1980).

\section{Transmission electronic microscope (TEM):}

Tissue specimens were cut into $2 \mathrm{~mm}$ cubes and fixed in $5 \%$ cacodylate buffered glutralaldehyde, post fixed in $1 \%$ osmium tetroxide, dehydrated in ascending grades of ethanol and embedded in Epon. Ultrathin sections were stained with uranyl acetate and lead citrate, and examined with Jeol 100cx EM ạt $80 \mathrm{Kv}$ (Robinson, 1982).

\section{Routes of experimental infection:}

1- Intradermal route: This method was done by scarification of skin and rubbing with about $0.05 \mathrm{ml}$ of stock virus.

2- Intravenous route: The wing vein was used for inoculation. Each bird was inoculated with $0.5 \mathrm{ml}$ of stock virus.

\section{Determination of host-range of isolated pox viruses:}

Each of the three isolated pox viruses was inoculated intravenously in four groups of birds. Groups 1 to 4 consisted of 10 day-old chicks, 10 pigeon squabs, 5 turkey poults and 5 ducks respectively. Birds were observed after inoculation for 2 weeks for clinical signs, lesions and mortalities. 


\section{Pathogenicity of isolated pigeon pox virus for pigeons:}

A total of 30 two-week-old pigeon squabs were divided into 3 groups, 1, 2 and 3 . The first two groups were infected with isolated pigeon pox virus (Pigeon origin) via intravenous and feather follicle routes respectively. The third group served as non infected control. All groups were observed for 2 weeks for clinical signs, lesions and mortalities.

\section{Field observations:}

\section{RESULTS}

In the last few years, 8 outbreaks of pox infections were observed in many pigeon lofts in Upper Egypt. The pathognomonic clinical signs for these outbreaks were cutaneous lesions which in some cases extended around the eyes leading to partial or complete closure of the eyes. Yellowish, diphtheritic membrane were observed in patches on mucous membranes of upper digestive and upper respiratory tracts.

Most of these pigeon lofts were located in isolated areas away from the villages and any source of infection. Some of exotic birds as doves and sparrows were observed in contact with these pigeons. Catching and examination of these exotic birds revealed presence of external cutaneous pox lesions.

\section{Chicken embryo inoculation:}

On the first passage in embryonated chicken eggs with undiluted virus suspensions, white thickening and coalesced pock lesions were observed. Inoculation of diluted virus suspensions produced a countable pock lesions which were more milliary and smaller in case of pigeons and doves isolates than sparrows isolate. The individual pocks were observed as central elevated white lesions surrounded by peripheral oedema.

\section{Haemagglutinating activity:}

The isolated pox viruses failed to agglutinate chicken RBCs.

\section{Heat stability:}

All virus isolates were inactivated at $56 \mathrm{C}$ for 30 minutes.

\section{Ether and chloroform sensitivity:}

The isolated pox viruses were resistant to ether and chloroform treatment. No reduction in virus infectivity was detected in treated samples in comparison to untreated control samples.

AGP test:

The reference fowl and pigeon pox viruses produced 3 lines of precipitation with homologous reference antisera. Positive reaction in AGP test was produced by isolated pox viruses against all tested reference 
antisera. The reaction against pigeon pox reference antisera was visible with 2 lines in comparison to one line against fowl pox and turkey pox antisera in case of pigeon and doves isolates, while the reaction against fowl pox reference antisera was visible with 2 lines in case of sparrows isolate in comparison to one line with either pigeon or doves isolates.

Virus neutralization test:

Results of virus neutralization test indicated that a complete neutralization was produced against reference pigeon pox antisera in case of pigeon and doves isolates and against fowl pox reference antisera in case of sparrows isolate.

\section{Histopathological findings:}

Histopathology of the skin lesions revealed epidermal hyperplasia. The cells of the stratum spinosum were enlarged and contained characteristic eosinophilic A-type cytoplasmic inclusion bodies (Bollinger bodies) (Fig.4,5). There were intra- and intercellular edema, acantholysis resulting in intraepidermal vesicles. Exocytosis of heterophilis into these vesicles resulted in formation of intraepidermal and subcorneal pustules (Fig.4). Orthokeratotic hyperkeratosis was also observed. The derms showed severe vascular engorgement, diffuse edema and perivascular lymphocytic infiltration (Fig.6).

\section{Transmission electron microscopy:}

Electron microscopy of the ultrathin sections revealed that the virus replication occurs the cytoplasm, and appeared early as a viroplasm. Viroplasm was surrounded by incomplete membranes which appeared to be closing together to form immature virus forms (Fig.7). The immature forms consisted of dense viroplasm surrounded by a double membrane. They often contained an electronic dense nucleoid (Fig.7). A multi-layered undulating lamellar structure or long filaments were frequently observed adjacent to the area of virus morphogensis. Viral forms in varying stages of completion were present along these structures (Fig.8,9). Intermediate viral forms were observed and characterized by an inner core similar to the early viroplasmic particles but surrounded by an additional coat. The mature forms were seen gather into cytoplasmic A-type inclusions. These inclusions contained masses of electron dense rodlets and virions. It has irrigular outer surface, (Fig. 10). The mature forms of the virus were brick-shaped or oval forms. It consists of centrally located biconcave core or nucleoid with a moderate electron density and two lateral bodies in each concavity and envelop. The core and inner membranes were constricted centrally giving a dumbbell-shaped appearance. 
The mature virions inside the inclusion body exhibited two additional coats over those outside the inclusion body (Fig.11). The innermost coat was thin and obtained by indentation during passage through the inclusion body membrane. The outer coat, thicker and more electron dense and formed from rodlets on the interior of the inclusion body. A small, round electron dense body was located in the outermost coat of these viral particles (Fig.11).

Hydropic degeneration of mitochondria was common in all infected cells. Numerous aggregates of lipid containing vacuoles surrounded by limiting membrane were also observed. Occasionally, small number of virions were seen surrounding these vacuoles (Fig.10). There were intercellular edema and desmolysis (Fig.9).

host-range of isolated pox viruses:

Study of pathogenicity of iso'ated pox viruses to different hosts (Table, 1) indicated that pigeon and doves isolates resulted in generalized pox lesions after intravenous inoculation in pigeon squabs, while these isolates failed to produce lesions in chickens, turkeys and ducks. Conterary to these, intravenous inoculation of sparrows isolate was associated with generalized pox lesions in chickens and turkeys, while no lesions were produced after inoculation of pigeons or ducks.

Pathogenicity of isolated pigeon pox virus for pigeons:

The results of this experiment (Table, 2) indicated that inoculation of pigeon squabs with pigeon pox virus (Pigeon origin) resulted in generalized pox lesions after intravenous or feather follicle routes, while the lesions were more severe after I/V inoculation than after feather follicle route.

Table (1): Host-range of isolated pox viruses from pigeons, doves and sparrows after $I / V$ inoculation.

\begin{tabular}{|c|c|c|c||}
\hline \multirow{2}{*}{ Species } & \multicolumn{3}{|c|}{ Isolate origin } \\
\cline { 2 - 4 } & Pigeon & Dove & Sparrows \\
\hline \hline Day-old-chick & 0 & 0 & $+\mathbf{G}$ \\
\hline Pigeon squabs & $+\mathrm{G}$ & $+\mathrm{G}$ & 0 \\
\hline Turkey poults & 0 & 0 & $+\mathrm{G}$ \\
\hline \hline Ducks & 0 & 0 & 0 \\
\hline 0 = no lesions.
\end{tabular}


Table (2): Pathogenicity of pigeon pox virus to 2-week-old pigeon squabs.

\begin{tabular}{|c|c|c|c|}
\hline $\begin{array}{c}\text { Route of } \\
\text { infection }\end{array}$ & $\begin{array}{c}\text { No. of } \\
\text { birds }\end{array}$ & $\begin{array}{c}\text { No. of } \\
\text { diseased }\end{array}$ & Lesions \\
\hline \hline I/V & 10 & 10 & $\begin{array}{c}\text { Generalized } \\
\text { skin lesions }\end{array}$ \\
\hline $\begin{array}{c}\text { Cutanous } \\
\text { route }\end{array}$ & 10 & 8 & $\begin{array}{c}\text { Generalized } \\
\text { skin lesions }\end{array}$ \\
\cline { 2 - 4 } & 5 & 0 & $\begin{array}{c}\text { Local skin } \\
\text { lesions }\end{array}$ \\
\hline $\begin{array}{c}\text { Non-infected } \\
\text { control }\end{array}$ & 5 & 0 \\
\hline
\end{tabular}

\section{DISCUSSION}

In this study the occurrence of infections with pox viruses in exotic birds was conducted through isolation and characterization of pox viruses. Three species of exotic birds were investigated, pigeons, doves and sparrows. Results of isolation and identification revealed that pigeons and doves isolates were pigeon pox virus, while the sparrows isolate was identified as fowl pox virus. Many authors could isolate or experimentally infect different species of exotic birds with pigeon pox (Kossack and Hanson, 1954; Cooper, 1969; Kraft and Teufel, 1971; Graham, 1978). All isolated pox viruses failed to agglutinate chicken RBCs and found to resist ether and chloroform treatment. These results are similar to those reported by Tripathy (1991).

The inoculation of embryonated chicken eggs produced thickening and oedema at the site of inoculation, while at the second passage, a countable pock lesions were observed at 5 th day postinoculation. No mortalities were observed in pigeon pox virus inoculated embryos, while mortalities after inoculation of fowl pox virus could be observed at 3-5th days postinoculation. Such results were also observed by Kar and Pathak (1980).

The characteristic feature of pigeon pox virus infection in the skin and mucous membranes of the infected pigeon squabs was hyperplasia of the epithelium of the dermis, enlargement of cells and cytoplasmic eosinophilic ATI. Similar results were described with other poxvirus infections (Tripathy, 1991) and in pigeons (Gomez-Villamandes et al., 1991) 
The ultrastructural investigation of the infected epithelial cells revealed that the early evidence of viral infection was the formation of viroplasm which was sequestered by membranes to form the viroplasmic particles. These particles undergo maturation by condensation and acquiring of an additional outer membrane to incomplete virion. Microfilaments were often associated with these forms. The incomplete virions migrate through the membrane of lipid containing vacuoles thereby obtaining a membrane coat. Rodlets produced within the inclusion body provide the external lipid coat of the virus. This mechanism of virus multiplication and its entrance into A-type inclusion with $\mathrm{V}^{+}$character was similar to other studies in chickens using strain of turkey origin (Cheville, 1966) and in canary (Sadasiv et al., 1985). The association of the incomplete virions with the filamentous structures may be related to the virus dissemination through the microvilli, which were observed by Hiller et al., (1979) in the later stages of infection with vaccinia WR or cowpox.

The irregular shape of the virus filled ATI could be attributed to the mechanical effect of numerous virions passing through and into the inclusion, thereby disrupting the inclusion body surface (Sadasiv et al., 1985). In conclusion, pigeon pox virus infection in squabs appears to be able to mature only by occluding in ATI. The function of the inclusion body is probably to provide an efficient mechanism of virus production

Characterization of isolated pox viruses on the basis of host-range pathogenicity revealed that pigeon and doves isolates resulted in generalized pox lesions after $I / V$ in pigeon squabs, while these isolates failed to produce lesions in chickens, turkeys and ducks. On the other hand, the sparrows isolate resulted in generalized pox lesions in chickens and turkeys, but no lesions were produced in pigeons or ducks. These results indicated that the pigeon and doves isolates were pigeon pox virus, while that isolated from sparrows was fowl pox virus. A similar result was also obtained by Mayr (1963).

The pathogenicity of pigeon pox virus (Pigeon origin) by different routes indicated that generalized pox lesions were produced after intravenous or feather follicle routes. These lesions were more severe after $\mathrm{I} / \mathrm{V}$ inoculation than feather follicle route.

It could be concluded that exotic birds are considered as an important source of pox virus infection to domestic birds. The present study pointed to the importance of electron microscopy in the rapid diagnosis of avian pox
viruses. 


\section{REFERENCES}

Andrews, C.H., and Horstmann, D.M. (1949): The susceptibility of viruses to ethyl ether. J. Gen. Microbiol. 3: 290-392.

Annon, (1971): Methods for examining poultry biologies and identifying and quantifying of pathogen. National Academy of Science, Washington, $\mathrm{DC}$

Back, A.; Soncini,R.A.; Ruthes, O.; Madureira, Jr. S. and Flores, R. (1995): An Atypical fowl pox outbreak in broilers in Southern Brazil. Avian Dis., 39: 902-906.

Baxendale, W.(1971): Studies on three avian pox viruses and the development of an improved fowl pox vaccine. Vet. Rec., 88: 5-9.

Cheville,N.F. (1966): Cytopathic changes in fowl pox (turkey origin) inclusion body formation. Am J. Pathol. 49: 723- 737

Cooper, J. E., (1969): Two cases of pox in recently imported peregrine falcons (Falco peregrinus). Vet. Rec. 85: 683-684.

Cunningham, C.H. (1966): A laboratory Guide in virology. 5th ed. Burgess Puplication Company, Minneapolis.

Cunningham, C.H. (1972): Avian pox. In Diseases of Poultry, 6th Ed. Edited by M. S. Hofstad. Iowa State University Press, Ames, IA.

Drury, R. A. B. and Wallington, E. A. (1980): Carleton's Histological technique. Fifth Ed. Oxoford Univ. Press, Oxoford.

El-Dahaby, H.; Sokkar, I.M.H; El-Sabbagh, A. H. and Nassar, M. I. (1971): Behaviour of an Egyptian fowl pox virus strain in tissue culture. J. Egypt. Vet. Med. Assoc., 8 No.2: 107-116.

Feldman, H. A. and Wang, S.S. (1961): Sensitivity of various viruses to chloroform. Proc. Soc. Exptl. Biol. and Med. 106: 736 - 740.

Gispen, R. (1955): Analysis of poxviruses antigens by means of double diffusion. A Method for direct serological differentiation of cowpox. J. Immunol. 74: 134-141.

Gómez-Villamandos, J.G.; Sierra, M.A.; Fernández, A.; Carrasco, L. and Jover, A. (1991): Simultaneous inclusion body hepatitis and pox lesions in two pigeons. Avian pathol. 20:173-177.

Graham, C. L. G. (1978): Pox virus infection in a spectacled Amazon parrot (Amazona albifrons). Avian Dis. 22: 340-343.

Hass, W. R. and Dardiri, A. H. (1968): Some properties of the virus of duck plaque. Arch. Für die Gesamt. Virus Forschung 24: 148-153.

Hiller, G.; Weber, K.; Schneider, L.; Parajsz, C., and Jungwirth, C.(1979): Interaction of assembled progeny pox viruses with the cellular cytoskeleton. Virol. 98: 142-153. 
Kar, B.C. and Pathak, R.C. (1980): Cultivation and titration of some avian pox viruses in developing chick embryo. Indian Vet. J. 57: 99-101.

Karstad, L. (1971): Pox. in J.W. Davis, R. C. Anderson, L. Karstad, and D.O. Trainer (eds), Infectious and Parasitic Diseases of Wild Birds, pp. 34-41. Iowa State Univ. Press, Ames.

Kirmse,P. (1967): Host specificity and long persistence of pox infection in the flicker (Coplaptes auratus). Bull Wildl Dis. Assoc. 3:14 -20.

Kraft, V. and Teufel, P. (1971): Nachweis eines Pockenvirus bei Zwergpapageien ( Agapornis personata und Agaporinis roseicollis). Berl. Münch. Tierärztl. Wschr.,5:83-87.

Kossack, C. w. and Hanson, H. C. (1954): Fowl pox in the Mourning dove. J. Am. Vet. Med. Assoc. 124: 199-200.

Matthews, R. E. F. (1982): Classification and nomenclature of viruses. Interviro'ogy, :7: 42-46.

Mayr, A. (1963): Neue Verfahren für die Differenzierung der Geflügelpockenviren. Berl. Münch. Tierärztl. Wschr., 76: 316.

Minbay, A., and Kreir, J.P. (1973): An experimental study of the pathogenesis of pox infection in chickens. Avian Dis., 17: 532-539.

Pandey, K.D. and Mallick, B.B. (1975): Cultivation of avian poxes in developing chick embryo. Indian J. Animal. Hlth. 14: 99-101.

Reed, J. L., and Muench, H. (1938): A simple method of estimating fifty percent end-points. Am. J. Hyg., 27: 493-497.

Robinson, G. (1982): Electron microscopy 2: Transmission (A) Tissue preparation; (B) Sectioning and staining. In Teory and Practice of Histological Techniques, 2nd ed. by Bamcroft, J. D. and Stevens, A. pp. 482-518. Churchill Livingstone, London and New york.

Sadasiv, E. C. ; Chang, P.W. and Gluka, G. (1985): Morphogenesis of canary poxvirus and its entrance into inclusion bodies. Am. J.Vet. Res. 46: 529-535.

Shida, H.; Tanabe, K. and Matsumoto, S. (1977): Mechanism of virus occlusion into A-type inclusion during poxvirus infection. Virol. 76:217-233.

Tripathy, D.H. (1991): Avian pox. In: Diseases of Poultry, Calneck, B. W.; Barnes, H. J.; Beard, C.W.; Reid, W. M., and Yoder, H. W. (Eds), 9th edn, pp. 198-212, Ames, Iowa State University Press.

Tripathy, D.H.; Hanson, L. E. and Killinger, A. H. (1973): Studies on differentiation of avian pox viruses. Avian Dis. 17: 325-333.

Tudor, D. C. (1995): Pigeon poxvirus infection. In: Pigeon Health and Disease. Iowa State Univ. Press, Ames, Iowa, USA. pp, 25-30. 


\section{LEGENDS OF FIGURES}

Fig. 1,2: Natural infection with pigeon pox in pigeon squabs.

Fig. 3: Experimental infection with pigeon pox in pigeon squabs.

Fig. 4: Light micrograph of the skin of infected squabs showing epidermal hyperplasia, acidophilic interacytoplasmic A-type inclusions in the epithelial cells, intraepidermal pustules and hyperkeratosis (H.\&E stain, x330).

Fig. 5: Higher magnification to demonstrate the acidophilic intracyto-plasmic A-type inclusion bodies and intercellular edma (H.\&E stain, x1320).

Fig. 6: Showing skin with cellular infiltration and edema of the derms (H.\&E stain, $\mathrm{x} 330$ ).

Fig. 7: Electron micrograph of an epithelial cell showing viroplasm (V), long filaments (F), viroplasmic particles associated with the lamellar filaments (arrow head), intermediate viral forms (arrow), nucleus (N), intercellular edema (E) and hydropic mitochondria (M). (Uranyl acetate and lead citrate stain, $\mathrm{x} 20,000$ ).

Fig. 8: Higher magnification of the preceeding micrograph showing viroplasm (V) sequestered by incomplete membrane (arrow head). Adjacent to these are viroplasmic particles containing nucleoids (arrow), microfilaments (f) and nucleus (N). (Uranyl acetate and lead citrate stain, x56,000).

Fig. 9: Higher magnification of Fig. 7 to demonstrate the intercellular edema (E), desmolysis (D), microfilaments (f). (Uranyl acetate and lead citrate stain, x56,000).

Fig. 10: Electron micrograph of an epithelial cell at late stage of viral infection showing accumulation of the mature viral particles into Atype inclusion (In), Note, an envolbe on its surface (arrow head), immature viral forms were free in the cytoplasm (arrow), and surrounding lipid vacuole (L), hydropic mitochondria (M), nucleus (N) and microfilaments (MF). (Uranyl acetate and lead citrate stain, $\mathrm{x} 10,800$ ).

Fig. 11: Higher magnification showing mature viral particles in the interior of the inclusion body (V) surrounded by the electron dense rodlets (R). Note investigation of the inclusion body membrane (arrow). The inset demonstrate the ultrastructural morphology of the mature pigeon poxvirus, core (Co), lateral bodies (LB), envelop (EN) and small round electron dense body (arrow head). (Uranyl acetate and lead citrate stain, $\mathrm{x} 10,800$ ). 
Assiut Vet. Med. J. Vol. 37 No. 73, April 1997
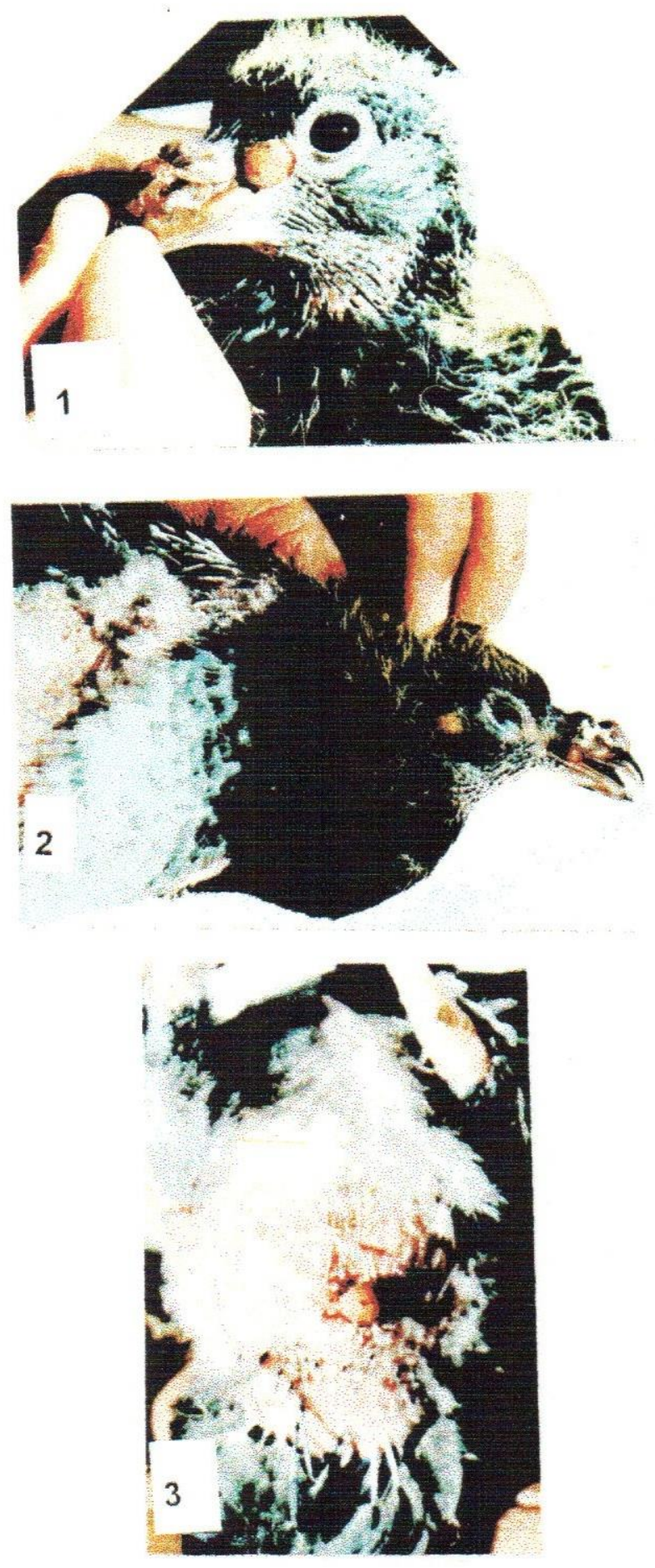


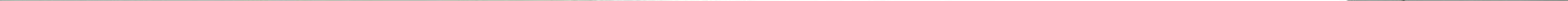




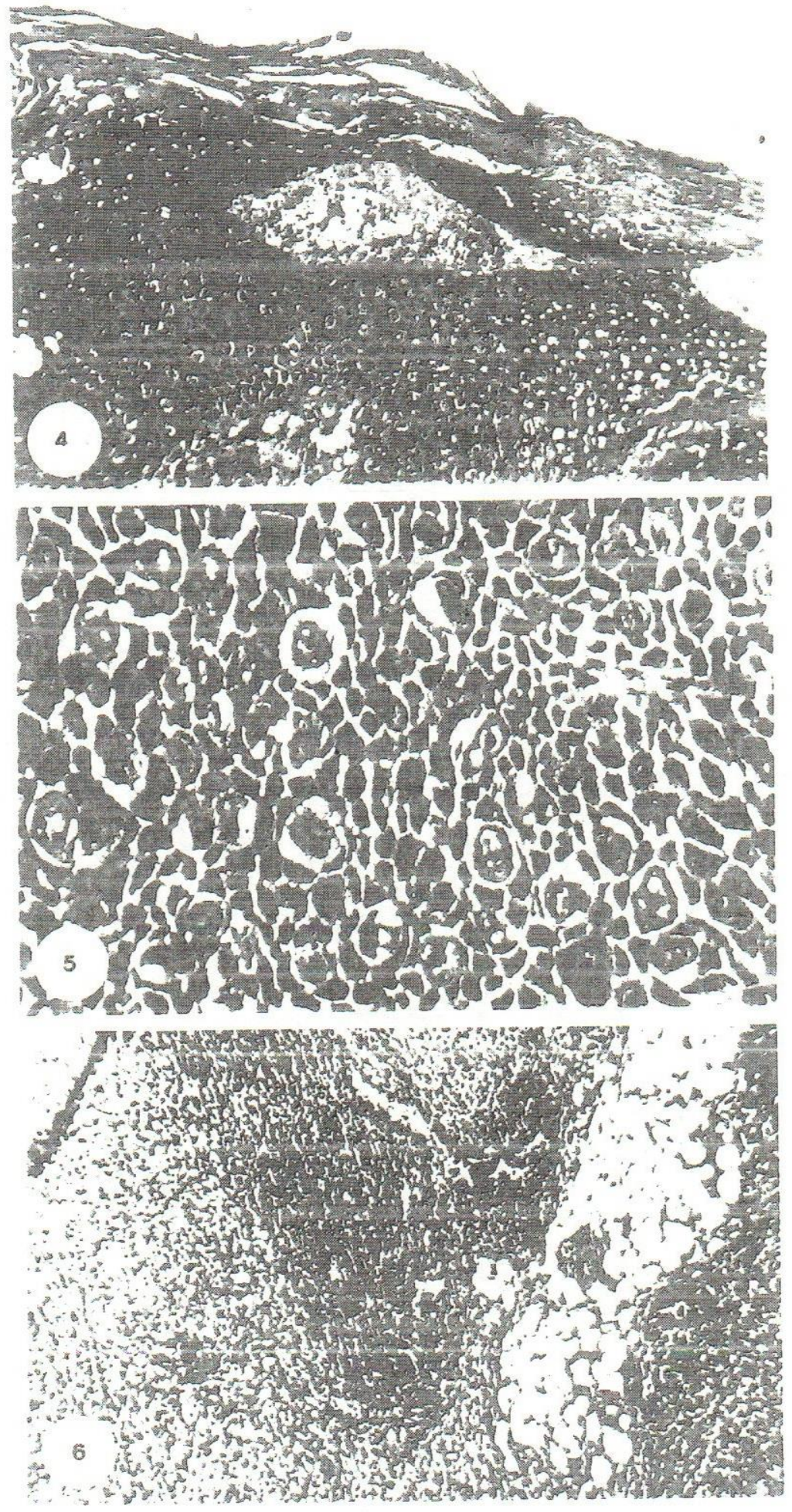




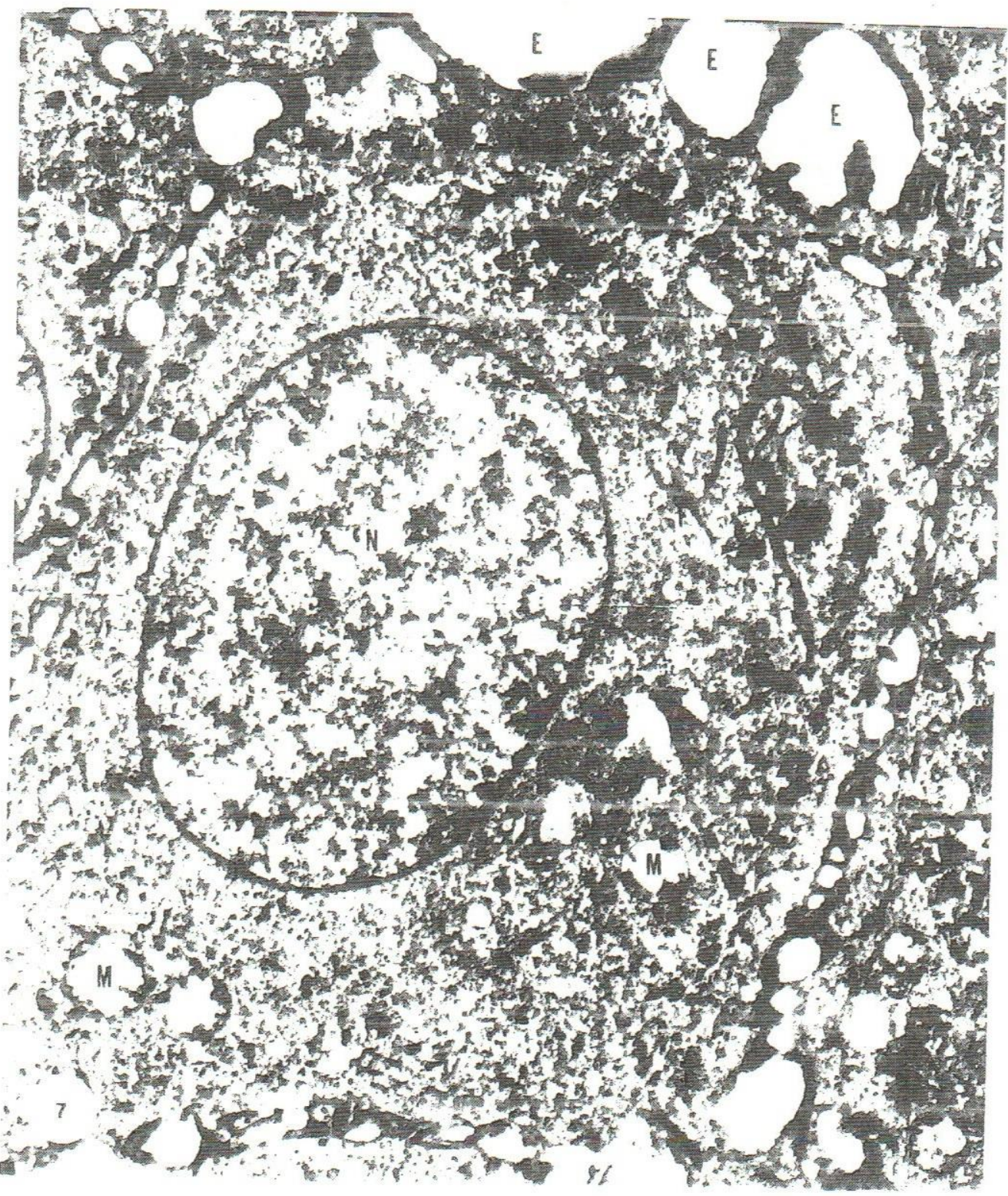


H.

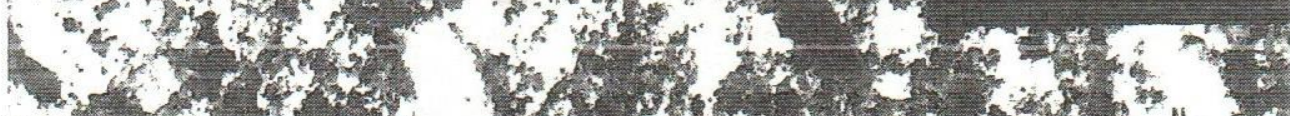

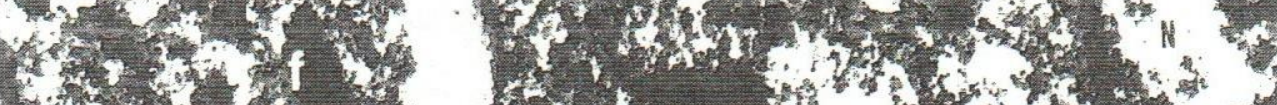

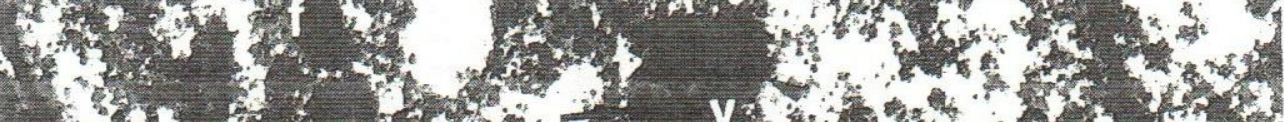

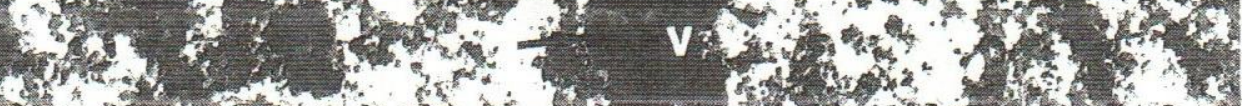

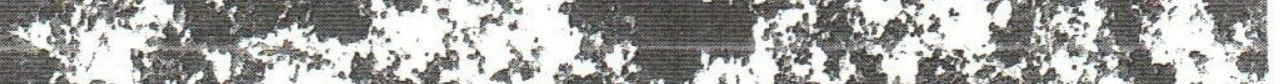

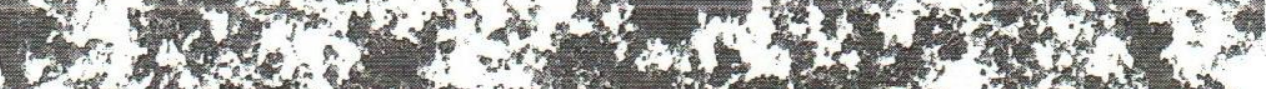

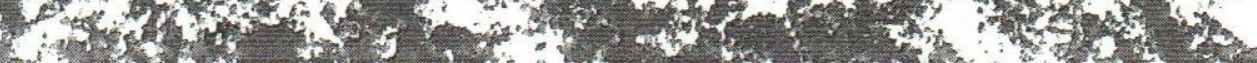

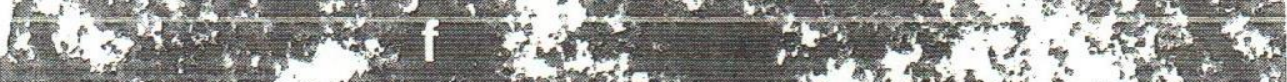

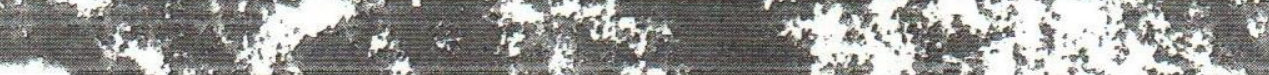

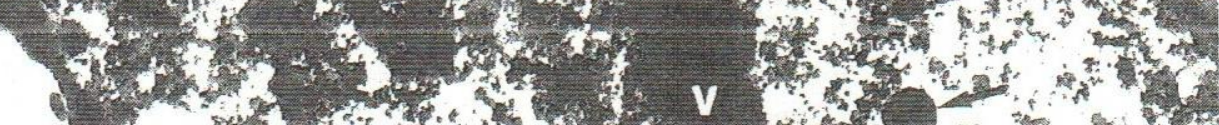

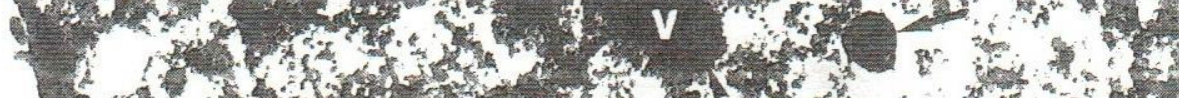
m.j.

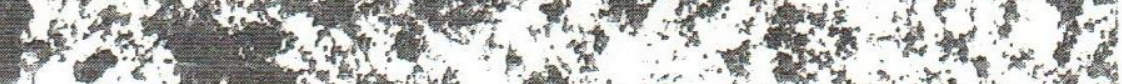

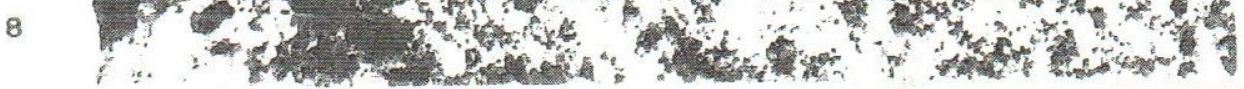

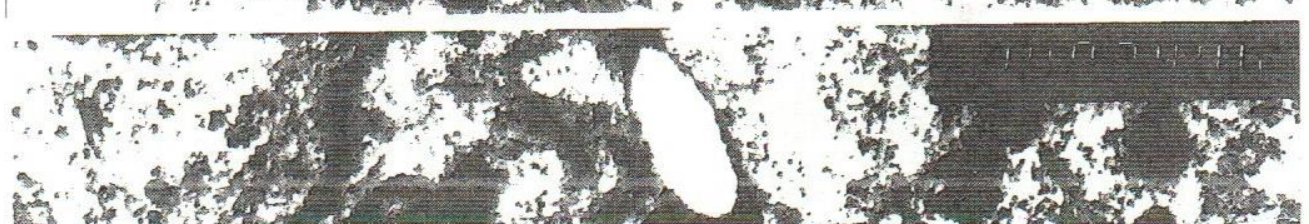

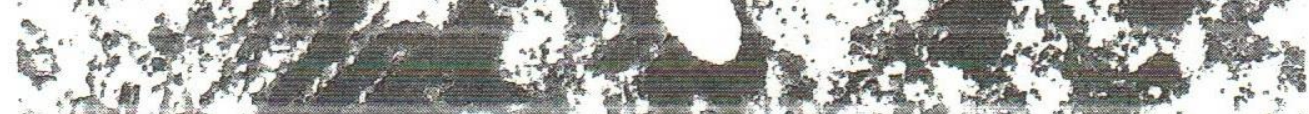

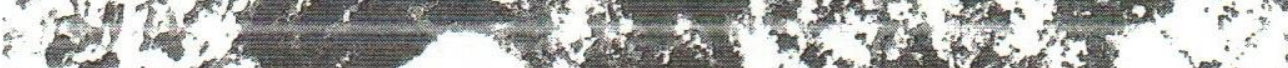

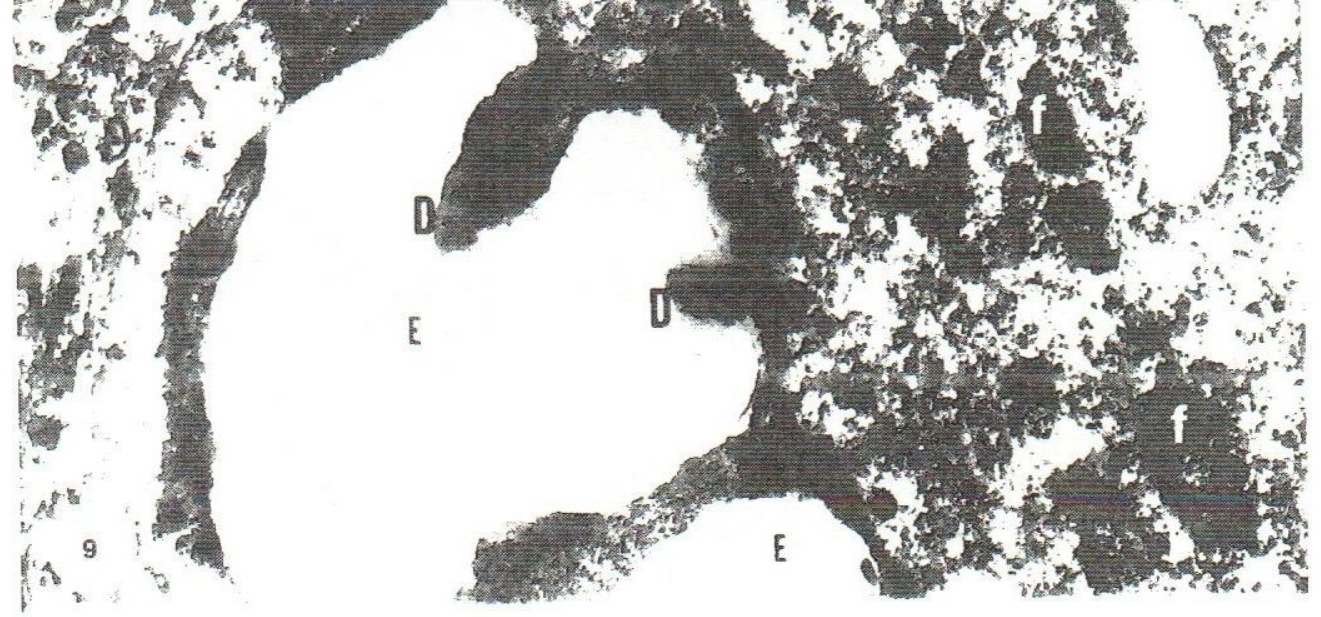




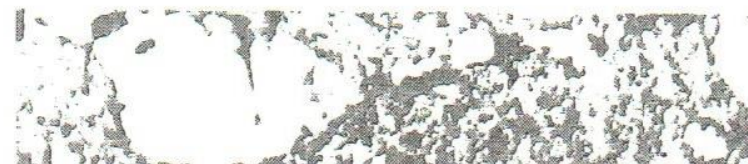

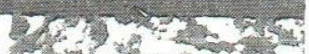

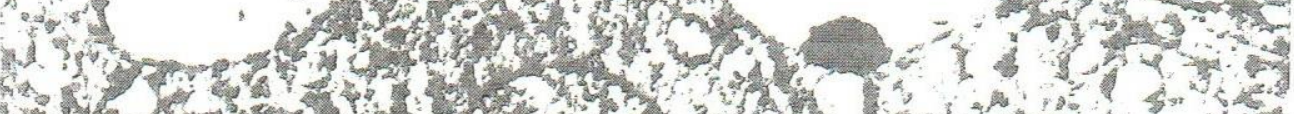

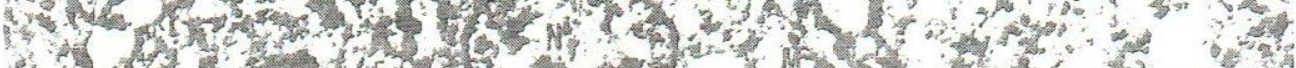
s.t.

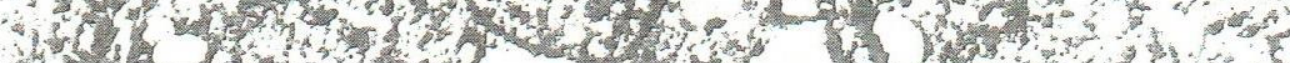

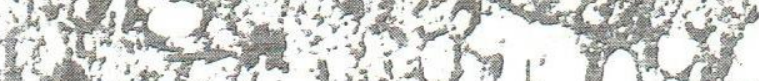
5 (D) He

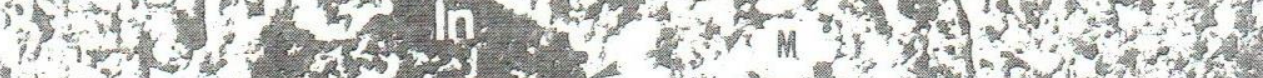

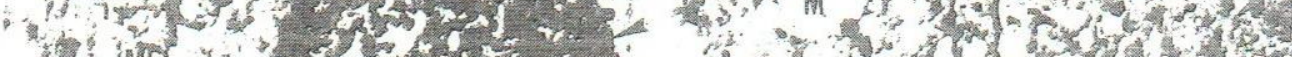

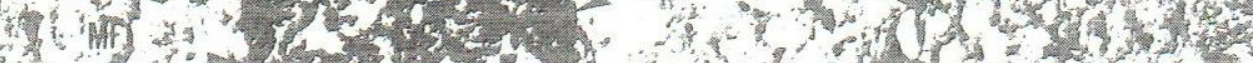

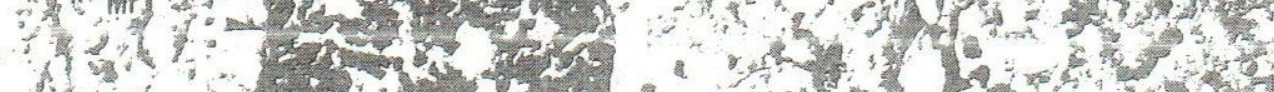

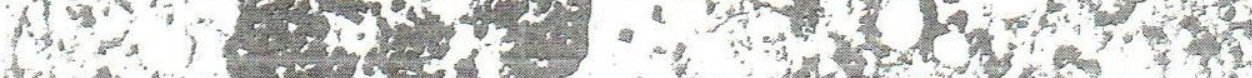

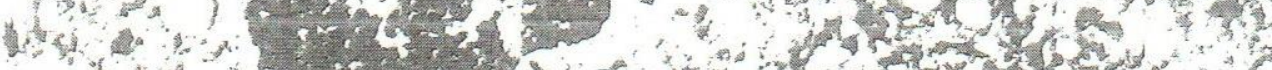
10 .

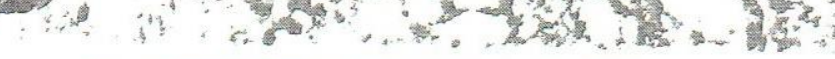

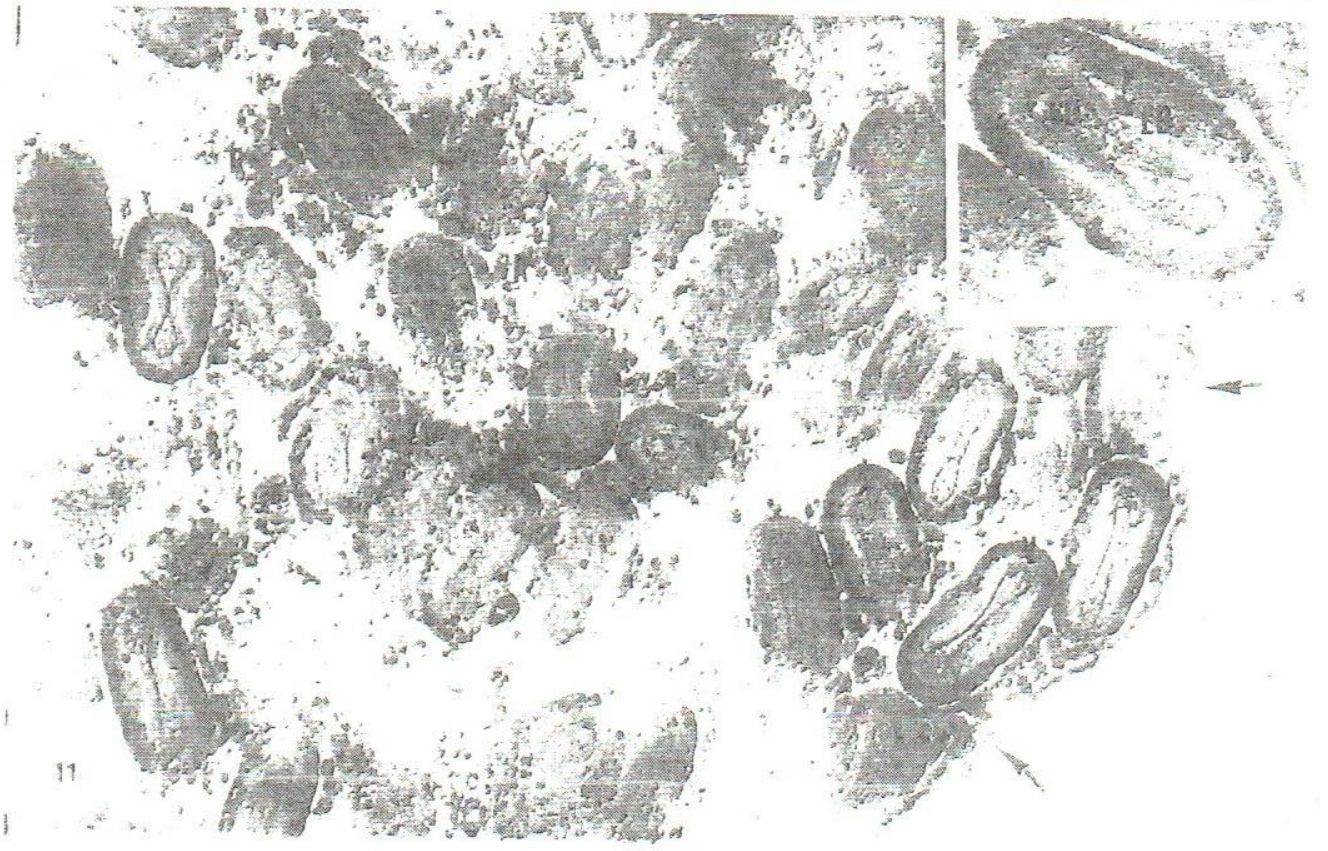

